\title{
CONTAMINATION OF APPARATUS DURING FREEZE-DRYING
}

\author{
By D. BUSBY \\ National Institute for Medical Research, Mill Hill, London, N.W. 7
}

(With Plate 7)

\section{INTRODUCTION}

A number of workers have reported that contamination of lyophilizing plant takes place during the drying of bacterial and viral suspensions (Stein \& Rodgers, 1950; Reitman, Moss, Harstad, Alg \& Gross, 1954). The Bacteriology and Virus Research Division of the National Institute for Medical Research uses a drying plant of the manifold type which is a modification of the Flosdorf \& Mudd 'Lyophile' apparatus (Flosdorf \& Mudd, 1935). The material dried on this apparatus consists mainly of virus suspensions. The volume in each tube is small, usually $0.1 \mathrm{ml}$., and up to 60 tubes can be dried in one operation. It has been the practice to dry living material in tubes with loose cotton-wool plugs. Not all workers agree with this, on the grounds that either the plugs restrict the flow of water vapour from product to condenser or that if they are so loose that vapour flow is not appreciably retarded they are ineffective as bacterial filters. It was not expected that virus particles themselves would be held back by cotton-wool filters but that small fragments of dried material which might be expelled from the tubes by vapour flow would be trapped. Apart from the danger of laboratory infections the possibility of contamination of one product by another is of the utmost importance. When drying Newcastle disease virus in ampoules without plugs, workers have recovered virus from the condensed vapour of the dried material (Stein \& Rodgers, 1950). The experiments to be reported here were carried out to estimate the advantages and disadvantages of drying with plugged tubes.

\section{MATERIALS AND METHODS}

Using the Melbourne strain of influenza virus, a series of experiments was carried out with a miniature glass manifold, with three side arms, connected by a length of pressure tubing to the drying apparatus (see Pl. 7, fig. 1). Cotton-wool was autoclaved in metal dental holders and plugs were made by 'teasing out' the wool with sterile forceps.

\section{Experiment 1}

Three tubes, with cotton-wool plugs, each containing $0.1 \mathrm{ml}$. of virus diluted 1:2 with skimmed milk, were shell frozen in a $\mathrm{CO}_{2}$-alcohol mixture at $-78^{\circ} \mathrm{C}$. and immediately attached to the manifold by short lengths of pressure tubing. When drying was complete, air was admitted through a calcium chloride drying bottle at the rate normally employed as routine. This rate will be referred to as 
'normal rate'.* The tubes were removed and the manifold was washed out with $1 \mathrm{ml}$. of $10 \%$ broth saline. This washing was inoculated into the allantoic cavity of 10-day fertile hen's eggs. The entire washing was always used to avoid the possibility of false negatives where the degree of contamination was small. To each $1 \mathrm{ml}$. of inoculum were added 200 units Penicillin and $200 \mu \mathrm{g}$. Streptomycin. After $48 \mathrm{hr}$. incubation at $37^{\circ} \mathrm{C}$. the allantoic fluid was harvested and the fluid from each egg tested for haemagglutinins against fowl red cells. $0.25 \mathrm{ml}$. of allantoic fluid was placed in a plastic-plate cup and an equal volume of $0.5 \%$ fowl cells added. No virus was recovered in this test (Table 1).

\section{Experiment 2}

Three unplugged tubes, each containing $0 \cdot 1 \mathrm{ml}$. virus + milk, were dried as for Expt. 1. The manifold washing was tested for virus in the same way. All eggs were positive (Table 1).

\section{Experiment 3}

Plugged tubes were used as in Expt. 1, but after 5 min. drying, warm water was applied to the tubes until partial thawing occurred with subsequent frothing. The heat was then removed and drying continued, the material immediately freezing under the reduced pressure. After drying was complete the manifold was washed out and the washing tested for virus as in the previous experiments. This washing gave negative results (Table 1 ).

\section{Experiment 4}

In Expt. 2 the dry air had, by accident, been admitted more rapidly than the normal rate, and it seemed likely that recovery of virus from the manifold washing might have been due to disturbance of the dried product by the inrush of air rather than to 'carry over' of the virus during the drying process. This seemed even more probable when on repeating this experiment with air admitted at normal rate no virus contamination could be demonstrated.

To test this theory more fully, three tubes without plugs and each containing $0.1 \mathrm{ml}$. virus + milk were attached to the manifold by slightly longer rubber connectors than usual. When drying was complete clips were applied to the rubber connectors above the tubes and air was admitted. The tubes were removed by cutting off the rubber connectors above the clips. The manifold washing was tested for virus with negative results (Table 1).

\section{Experiment 5}

As in Expt. 4, tubes without plugs were used but, after drying, air was admitted rapidly without applying clips to the connectors. All the eggs receiving the manifold washing were positive (Table 1).

* The rate of flow was not estimated, but a capillary tube inserted in the system allowed a certain measure of control of air admission. 


\section{Experiment 6}

In these earlier tests the manifold had been connected directly to the drying apparatus, and it had not been possible to test for virus beyond the manifold. A small condenser was constructed and placed between the manifold and the drying plant ( $\mathrm{Pl}$. 7, fig. 2). The condenser was cooled with $\mathrm{CO}_{2}$-alcohol and the water vapour condensed during drying was inoculated into eggs in the same way as in the treatment of the manifold washings.

Three tubes without plugs and each containing $0 \cdot 1 \mathrm{ml}$. virus + milk were dried as in previous tests and air admitted at normal rate (Table 2).

Table 1. Effect of plugging tubes on contamination of manifold washings

\begin{tabular}{|c|c|c|c|}
\hline Expt. no. & $\begin{array}{l}\text { With }(+), \\
\text { without }(-) \\
\text { plugs }\end{array}$ & Other modifications & $\begin{array}{l}\text { HA test for virus, } \\
\text { manifold washing }\end{array}$ \\
\hline 1 & + & - & --- \\
\hline 2 & - & . & $+t+t$ \\
\hline $\mathbf{3}$ & + & Thawed with frothing & -- \\
\hline 4 & - & $\begin{array}{l}\text { Clips between tubes } \\
\text { and manifold }\end{array}$ & -- \\
\hline $\mathbf{5}$ & - & Rapid air admission & $++t+$ \\
\hline
\end{tabular}

+ and - signs to right of table indicate presence or absence of virus as shown by haemagglutination.

Table 2. Contamination of manifold washings and condensate

\begin{tabular}{|c|c|c|c|c|c|c|c|c|c|c|}
\hline \multirow{3}{*}{$\begin{array}{l}\text { Expt. } \\
\text { no. } \\
6\end{array}$} & \multirow{3}{*}{$\begin{array}{c}\text { With }(+) \\
\text { without }(-) \\
\text { plugs } \\
-\end{array}$} & \multicolumn{9}{|c|}{ HA test for virus } \\
\hline & & \multirow[t]{2}{*}{ Other modifications } & \multicolumn{4}{|c|}{$\begin{array}{l}\text { Manifold } \\
\text { washing }\end{array}$} & \multicolumn{4}{|c|}{ Condensate } \\
\hline & & & - & + & + & - & - & - & - & - \\
\hline 7 & - & Rapid air admission & + & + & + & + & - & - & - & - \\
\hline 8 & + & $\begin{array}{l}\text { Constricted tubes, rapid } \\
\text { air admission }\end{array}$ & - & - & - & - & - & - & - & - \\
\hline 9 & - & $\begin{array}{l}\text { Constricted tubes, rapid } \\
\text { air admission }\end{array}$ & + & + & + & + & + & + & + & + \\
\hline 10 & + & $\begin{array}{l}\text { Constricted tubes, normal } \\
\text { air admission }\end{array}$ & - & - & - & - & - & - & - & - \\
\hline 11 & - & $\begin{array}{l}\text { Constricted tubes, normal } \\
\text { air admission } \\
+ \text { and - signs as in Table }\end{array}$ & + & + & + & + & & + & - & - \\
\hline
\end{tabular}

\section{Experiment 7}

The procedure was the same as Expt. 6 but with rapid air admission (Table 2).

\section{Experiments 8-11}

In an effort to test more fully the effect of the air inrush upon the dried material, tubes were constricted slightly to prevent the plug from being pushed down when the air was admitted rapidly. The constrictions were made about one-quarter of 
the tube length from the neck. A further series of experiments was carried out using constricted tubes with other modifications (Table 2).

After each drying cycle one tube of the dried product was reconstituted and tested for virus in eggs. The results were positive in all tests.

\section{SUMMARY}

When the manifold system of freeze-drying is used the practice of plugging the tubes containing the product to be dried would seem to be necessary. It should be emphasized that a loose plug implies teased out cotton-wool and not just a loosely fitting one. Virus was recovered from the drying apparatus under various conditions when unplugged tubes were used. No virus contamination could be demonstrated when the tubes were plugged.

\section{REFERENCES}

Flosdorf, E. W. \& Mudd, S. (1935). Procedure and apparatus for preservation in 'Lyophile' form of serum and other biological substances. J. Immunol. 29, 389.

Reitman, M., Moss, M. L., Harstad, J. B., Alg, R. L. \& Gross, N. H. (1954). Potential infectious hazards of laboratory techniques. I. Lyophilization. J. Bact. 68, 541.

Stein, C. D. \& Rodgers, H. (1950). Recovery of viable micro-organisms and viruses from vapours removed from frozen suspensions of biologic material during lyophilization. Amer. J. Vet. Res. 11, 339.

\section{EXPLANATION OF PLATE}

Fig. 1 see p. 403

Fig. 2 see p. 405

(MS. received for publication 6. vII. 59) 

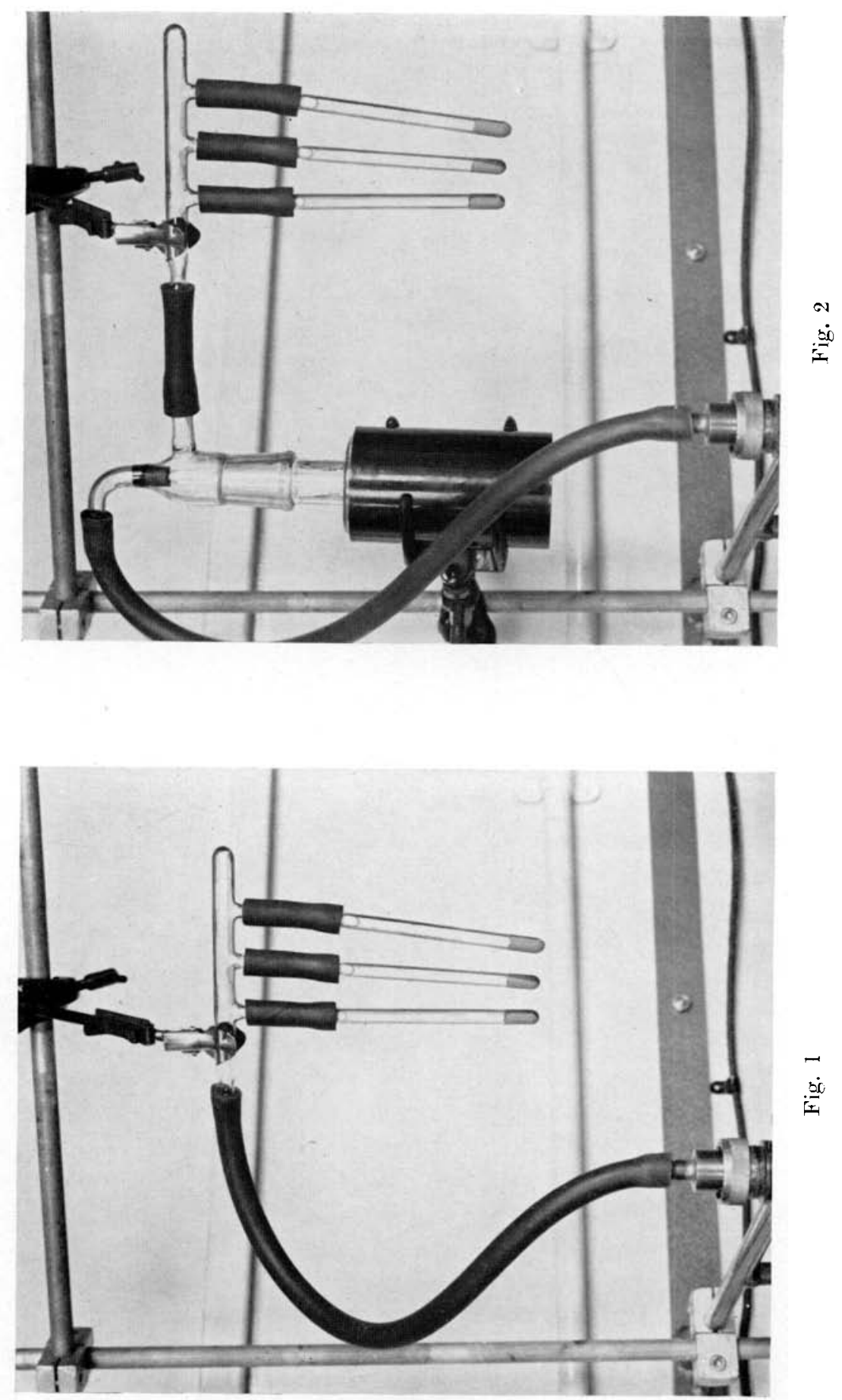